\begin{tabular}{|l|l|l||}
\hline \multicolumn{2}{|c|}{ PublisherInfo } \\
\hline \hline PublisherName & $:$ & BioMed Central \\
\hline \hline PublisherLocation & $:$ & London \\
\hline \hline PublisherImprintName & $:$ & BioMed Central \\
\hline \hline
\end{tabular}

\title{
Molecular pathway for Monarchs
}

\begin{tabular}{|l|l|l||}
\hline \multicolumn{2}{|c|}{ ArticleInfo } \\
\hline \hline ArticleID & $:$ & 5085 \\
\hline \hline ArticleDOI & $:$ & $10.1186 /$ gb-spotlight-20050506-02 \\
\hline \hline ArticleCitationID & $:$ & spotlight-20050506-02 \\
\hline \hline ArticleSequenceNumber & $:$ & 61 \\
\hline \hline ArticleCategory & $:$ & Research news \\
\hline ArticleFirstPage & $:$ & 1 \\
\hline \hline ArticleLastPage & $:$ & 3 \\
\hline \hline & & RegistrationDate : 2005-5-6 \\
\hline ArticleHistory & $:$ & OnlineDate \\
\hline \hline ArticleCopyright & $:$ & BioMed Central Ltd2005-5-6 \\
\hline \hline ArticleGrants & $:$ & \\
\hline \hline ArticleContext & $:$ & 130596611 \\
\hline \hline
\end{tabular}


For the first time, researchers working on migratory Monarch butterflies have identified a molecular pathway possibly linking the creature's central circadian clock to photoreceptors involved in its "sun compass"-which the butterfly uses to orient its flight during migration. Their findings are published in this week's issue of Neuron.

"We've known for a while that the circadian clock plays a role in the Monarch butterflies' timecompensated navigational system, but the molecular mechanisms are still a mystery," said coauthor Steven Reppert, from the University of Massachusetts Medical School in Worchester.

To maintain the constant direction of their navigation during their fall journey south from the northern United States and Canada to Mexico, Monarch butterflies are known to use guideposts of the daylight sky. The most consistent of these references is the sun, but other celestial cues also come into play, such as polarized light reflecting from the sun. Another indispensable factor for keeping a fixed orientation despite the movement of the sun during the day is the butterfly's ability to compensate time.

"In order for the butterfly to maintain its direction when the sun is moving through the sky, it has to change its angle of flight in respect to that of the sun," said Lincoln Brower from Sweet Briar College in Sweet Briar, Va., who did not participate in the study.

To provide a link between the clock and the compass, the team performed three series of experiments focusing on polarized light inputs. By cloning the cDNA of different visual pigment-encoding opsins in the eye, the researchers first characterized the photoreceptors sensitive to radiation light. While most regions of the retina expressed all different types of opsins, the polarized specialized dorsal rim area of the eye was monochromatic for ultraviolet (UV) opsins.

The team then performed behavioral studies using a flight simulator with a polarized light filter, to confirm that UV light is the wavelength that affects the polarized light receptors. They observed that in the absence of direct light from the sun, the butterflies still adapted their orientation to that of the moving filter. "But when UV inputs were blocked, the butterflies started flying in circles," Reppert told The Scientist.

In the third step, the team used immunocytochemistry to identify the presence of the Period and Timeless genes - which are thought to code for the circadian clock when expressed together. The genes were expressed in the dorsolateral protocerebrum of the butterfly's brain, in a rhythmic pattern. Using cryptochrome staining, a known circadian photoreceptor in the fly, the team was also able to detect a neural pathway that they said may connect the circadian clock to the polarized light inputs entering the dorsal rim area.

"These findings are very different from what you find in flies and in most other similar models," said Claude Desplanfrom New York University, who did not participate in the study. "Flies, for instance, have their own clock in the photoreceptors themselves, which affects how these photoreceptors modulate their own sensitivity to light. Here, there is a direct connection with the central clock through the CRY [cryptochrome] neurons. It may be that flies also have a direct connection between the photoreceptors and the central clock." 
Now that a possible anatomical link has been identified between these two components, the next step will be to try and find out through electrophysiological studies if this pathway does transmit timecompensated information. "But because other cues are involved, there are probably other pathways we still don't know of that connect the clock to the different aspects of the sun compass," noted Reppert.

\section{References}

1. B.A. Palevitz, "The march of the Monarch," The Scientist, 16:26, October 14, 2002., [http://www.thescientist.com/2002/10/14/26/1]

2. I. Sauman et al., "Connecting the navigational clock to sun compass input in Monarch butterfly brain," Neuron, 46:457467, May 5, 2005., [http://www.neuron.org/content/article/ abstract?uid=PIIS0896627305002369]

3. Steven M. Reppert, [http://www.umassmed.edu/neuroscience/faculty/reppert.cfm?start=0]

4. Lincoln P. Brower, [http://www.biology.sbc.edu/faculty/HomePageLPB.html]

5. L. Hrastar, "Opsin mediates circadian clock," The Scientist, January 28, 2005., [http://www.thescientist.com/news/20050128/02]

6. T. Bloom, "Seeing the light," The Scientist, September 6, 2002., [http:/www.the-scientist.com/news/ 20020906/02]

7. Claude Desplan, [http://www.nyu.edu/fas/dept/biology/faculty/desplan/] 